\title{
Annual black bands in skeletons of reef corals (Scleractinia)
}

\author{
R. P. M. Bak \& R. W. P. M. Laane* \\ Netherlands Institute for Sea Research (NIOZ), PO Box 59, 1790 AB Den Burg, Texel, The Netherlands
}

\begin{abstract}
Dark discolorations appear concentrated as black bands in the fresh skeletons of massive reef corals (Porites), often restricted to the upper $7.5 \mathrm{~cm}$ of the coral skeleton. The pattern of these bands runs parallel to that of the skeletal density bands, the black bands occurring in the low density part of the pairs of high/low density bands. The black bands do not result from the inclusion of foreign material by the coral but are characterized by high concentrations of a dark fungus. We suggest that the dark banding pattern correlates to an annual variation in the organic content of the skeleton. Highest concentrations of the dark mycelia are reached where the fruiting bodies are formed. The fruiting bodies occur in groups and open through small dead areas on the living coral surface into the surrounding seawater. We found infected colonies in 6 massive Porites species but only at 2 locations, Salayer and Take Bone Rate (Southwest Sulawesi), in the eastern Indonesian Archipelago. At these locations up to $33 \%$ of the colonies showed the fungus discolorations. There appears to be no obvious effect on the strength of the coral skeletons; the main ecological effect of the fungus is that the formation of fruiting bodies interferes with the integrity, maintenance and growth of the living coral surface. This is the first example of a fungus being involved in spatial competition on coral reefs.
\end{abstract}

\section{INTRODUCTION}

The formation of skeletal material is intimately coupled to metabolic processes in organisms and variations in these processes can leave their record in the relatively durable skeletons. Exoskeletons, which are exposed to the environment, are subjected to additional sources of variation. Consequently, such skeletons are a potentially rich source of information on the history of an organism.

A good example of hard tissues containing records of past processes and events are the skeletons of stony corals (Scleractinia). Studies of coral skeletons have shown that there are at least 3 fields of interesting information: variations in the chemistry and density of the original skeleton (Knutson et al. 1972, St. John 1974, Flor \& Moore 1977, Dodge \& Vaisnys 1980), possible inclusion of dead organic and inorganic matter of various origin (Barnard et al. 1974, Dodge et al. 1984, Cortes \& Risk 1985, Boto \& Isdale 1985), and the activities of other organisms in the skeleton (Bak 1976, Hutchings 1986).

\footnotetext{
- Present address: DGW-AOC, PO Box 20904, 2500 EX The
} Hague, The Netherlands
The information contained in the skeletal record is particularly interesting if it can be related to specific events which happened at certain definite points in time, such as deforestations (Cortes \& Risk 1985), nuclear explosions (Knutson et al. 1972) or abnormally low temperatures (Hudson et al. 1976). Sometimes the variations in skeletal characteristics show a regular recognizable pattern through time, with time intervais ranging from centuries (Druffel 1982) to years and months (Buddemeier et al. 1974, Buddemeier \& Kinzie 1975, Macintyre \& Smith 1974) and possibly days (Wells 1963, Barnes 1972). Such regular patterns are identified as variations in skeletal density (Knutson et al. 1972, Hudson et al. 1976), in stable isotope composition (Emiliani et al. 1978, Druffel 1982), in fluorescence of fulvic and humic acids (Isdale 1984) and densities of endolithic algae (Lukas 1973, 1974, Highsmith 1981). Sometimes such variations are easily visible as a regular pattern of bands of alternating characteristics (Ma 1934, Highsmith 1981).

We found an unknown pattern of blackish discolorations during a study of the skeletons of massive living Porites colonies, collected in Indonesia during the Snellius II expedition. These black to greyish discolorations occurred in distinct spots but also in clearly distin- 
guishable bands that often displayed a regularly repeated banding pattern throughout the skeleton. Such dark banding patterns are not known from the skeletons of living marine organisms and our first question was: Are these of inorganic or organic origin?

Here we report on the characteristics of these black discolorations and bands, their occurrence in the corals and on the relation of the banding with previously described banding patterns.

\section{MATERIAL AND METHODS}

We collected samples of 226 living colonies of massive Porites species at 36 localities between 2 September and 30 October 1984 . These 36 localities represent 8 distinct geographic areas in the eastern part of the Indonesian Archipelago (Fig. 1). All samples were obtained at depths between 6 and $11 \mathrm{~m}$ on seawardfacing reef slopes.

The corals were processed aboard ship within $24 \mathrm{~h}$ after collection. A rotary rock-cutting saw was used to section the coral colonies in the plane of maximum growth, parallel to the direction of corallites, in order to obtain ca $4 \mathrm{~mm}$ thick slabs of skeleton. The slabs were X-radiographed (Buddemeier 1978) to reveal the skeletal density bands. When such bands were clearly present, which is not always the case (e.g. Weber et al
1975), distances between bands were measured and the position recorded. Black bands were similarly measured and their position was established in relation to the density pattern.

In the laboratory a series of analyses for inorganic and organic material on samples from the black bands and on controls was performed. For controls we used samples from areas in the skeleton without any visible discoloration or inclusion. The control samples were from corals displaying black discolorations in other parts of the skeleton and from colonies without any blackish discoloration.

To obtain information on the mineralogy of the samples we employed X-ray powder diffraction and EDAX analysis. Standard atomic adsorption techniques and EDAX were used to check for the inclusion of inorganic foreign elements. To study the possible inclusion of organic material pre-weighed samples were extracted with $1 \mathrm{~N} \mathrm{HCl}$ or $0.1 \mathrm{~N} \mathrm{NaOH}$. Dissolved organic carbon was measured after filtration over a pre-combusted glassfibre filter $\left(4 \mathrm{~h}, 480^{\circ} \mathrm{C}, 0.45 \mu \mathrm{m}\right.$, see Laane 1982). Particulate organic matter was measured directly on the filters by a wet-oxidation method (Laane ibid.). The fluorescence of the filtrate was expressed in millifluorescence ( $\mathrm{mFl}$ ) (Laane \& Koole 1982). The possible role of endolithic organisms was studied after dissolution of skeletal material in EDTA with (stereo)microscopes.

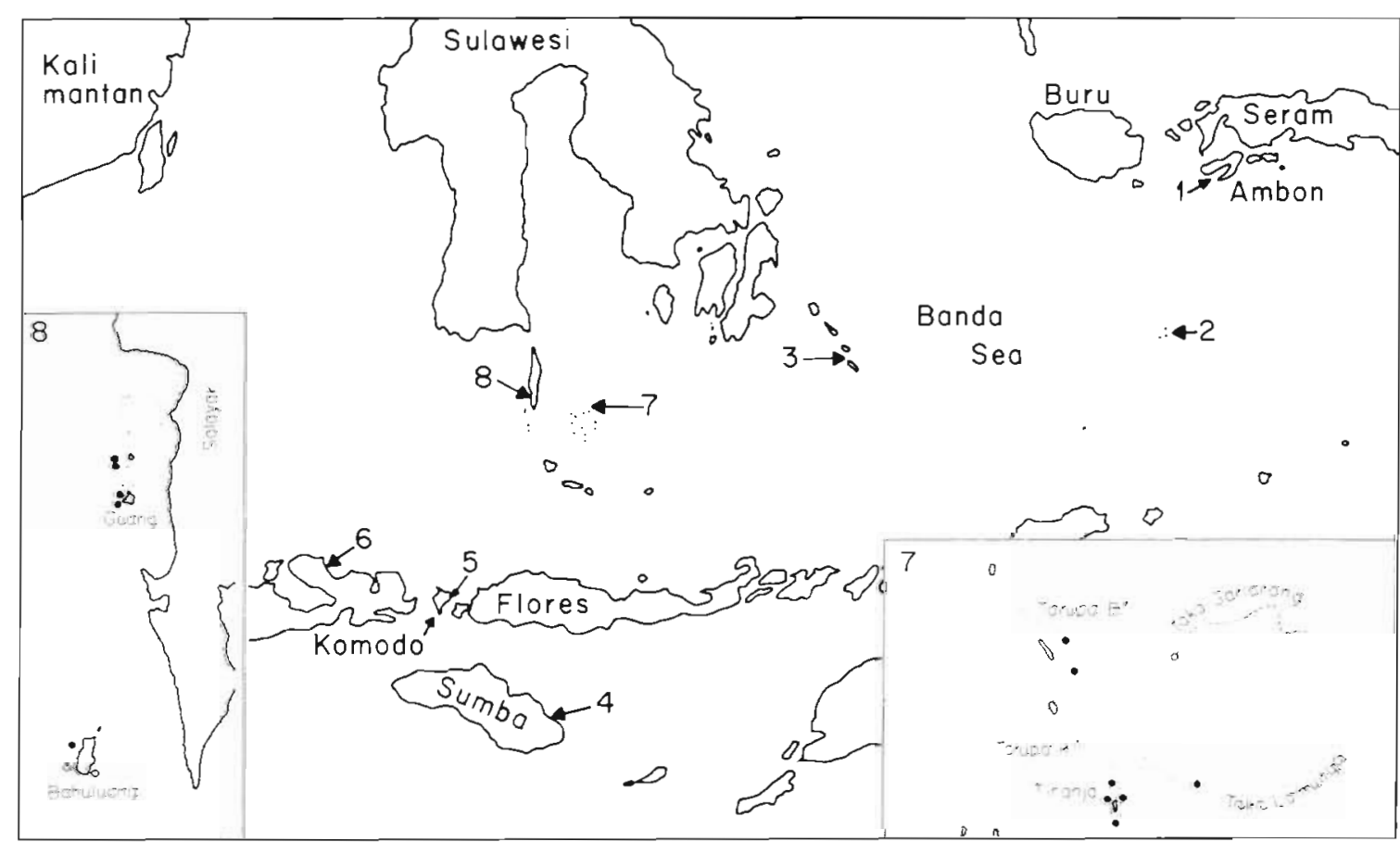

Fig. 1. Map of Banda and Flores Sea, Indonesia, showing the 8 different areas sampled for Porites skeletons (arrows); 1 , Ambon; 2 , Pulau Pulau Maisel; 3, Tukan Besi; 4, Northeast Sumba; 5, Komodo; 6, Northeast Sumbawa; 7, Take Bone Rate; 8, Salayer. Insets indicate locations of sampling sites in the Take Bone Rate (7) and off Salayer (8): (•) fungus present in samples, (o) no fungus present in samples 


\section{RESULTS}

Typical samples of a blackish Porites skeleton, displaying a generally greyish-black discoloration as well as the distinct black banding, are shown in Fig. 2. The maximum distance of bands from the coral polypary surface towards the base of the colony was $19 \mathrm{~cm}$ in our sample. But because the size of our samples never exceeded $19 \mathrm{~cm}$, this is probably not the absolute maximum distance. In a sizeable part $(43 \%)$ of all discolored colonies $(n=23)$ the bands and blots were restricted to the upper $7.5 \mathrm{~cm}$ of skeletal material. The black bands either occurred regularly spaced or wider light-colored areas interrupted the regular spacing of the black bands. The discolorations were not related to the occurrence of any of the common macroboring organisms such as excavating sponges (Clionidae) or sipunculid or polychaete worms. The black bands curve or meander parallel to each other through the slabs. The X-ray photographs revealed that the black bands in each coral closely follow the pattern of high/ low density bands: the black bands occurring in the low density bands.

It appeared from $X$-ray diffraction and EDAX analyses that the blackish skeletal material was pure aragonite. There was no evidence of FeS (pyrite), which is a likely component in anaerobic conditions, a potential source of blackish discolorations. The only inorganic material present besides aragonite was some $\mathrm{Cu}$ ( $3 \mathrm{ppm}$ ) and a trace of Sr, which could not be connected with the discolorations.

The fluorescence of dissolved material indicated the presence of fulvic and humic acids (Fig. 3). However, fluorescence and absorption per gram coral decreased rapidly within the first $2 \mathrm{~cm}$ from the polypary surface to a typical even level. There was no variation related to the skeletal density or to the black banding pattern. Measurements of fluorescence of intact slabs of skeleton, to establish the influence of greater skeletal density on a possible relation of fluorescence and density banding, gave no reproducible results. This is because of the rugosity of the slab surfaces, inherent to the porous structure of the coral skeleton, which interfered with the beam reflection from the slab surface.

Carbon analyses of skeletal samples showed particulate organic carbon (POC) as well as dissolved organic carbon (DOC) to vary regularly with distance to the polypary surface. These variations are significantly correlated with the dark banding pattern, maximum concentrations occurring in the black bands (Fig. 4, sign test, $\mathrm{p}<0.05, \mathrm{n}=13, \mathrm{n}=17$ ).

Partial dissolution (EDTA) of parts of the black bands revealed the presence of intricate networks of branched filaments. These structures are dark, grey to
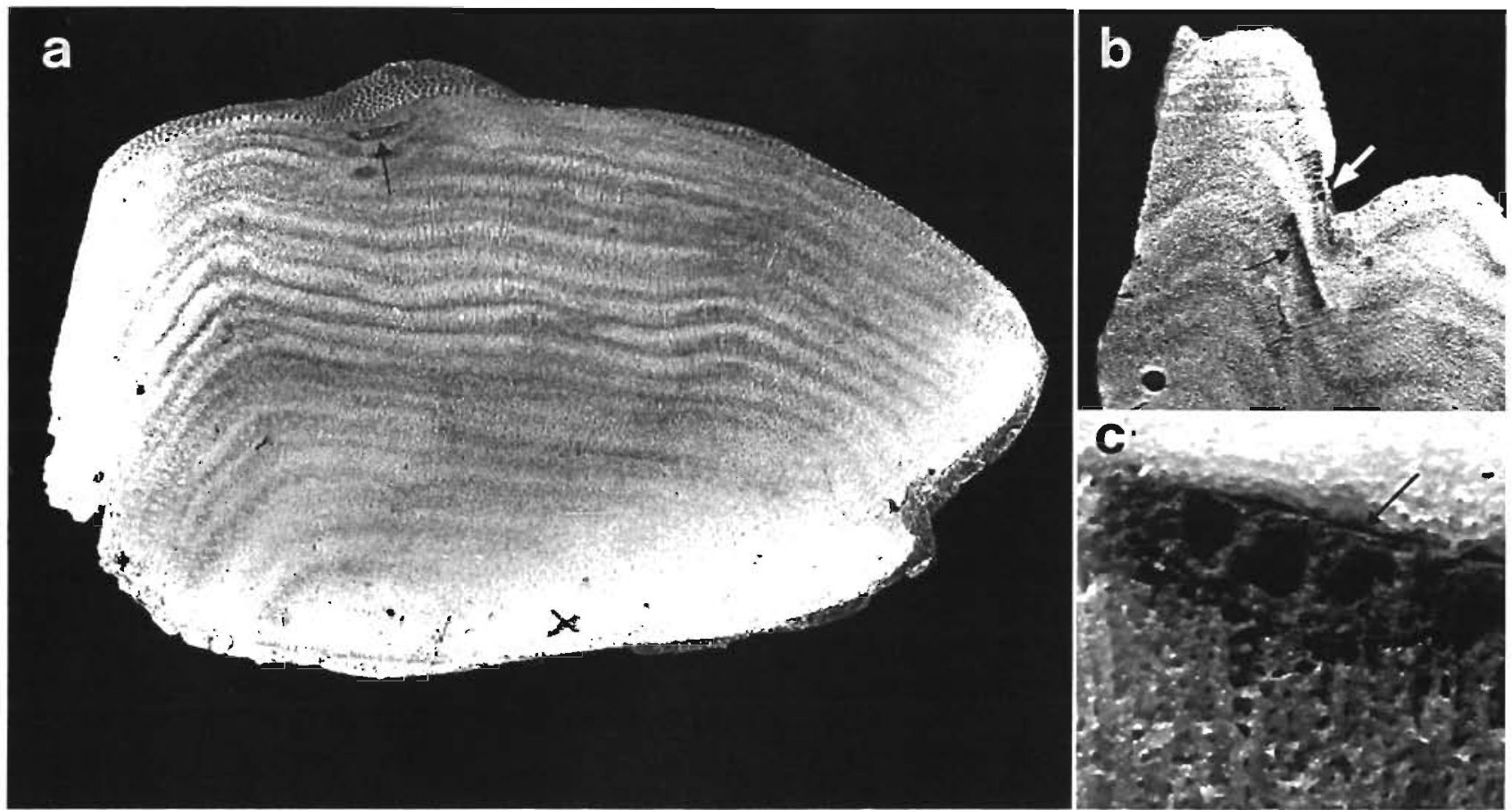

Fig. 2. Sections of massive Porites colonies displaying dark discolorations. (a) Porites lutea, Salayer. Regular dark banding reflecting the annual banding pattern. (b) Porites mayori, Take Bone Rate. Perithecia of fungus occur as galleries of fruiting bodies and show a high concentration of dark mycelium. Note presence of perithecia at colony surface (white arrow). (c) Detail of perithecia with dead and overgrown coral surface (arrow) 


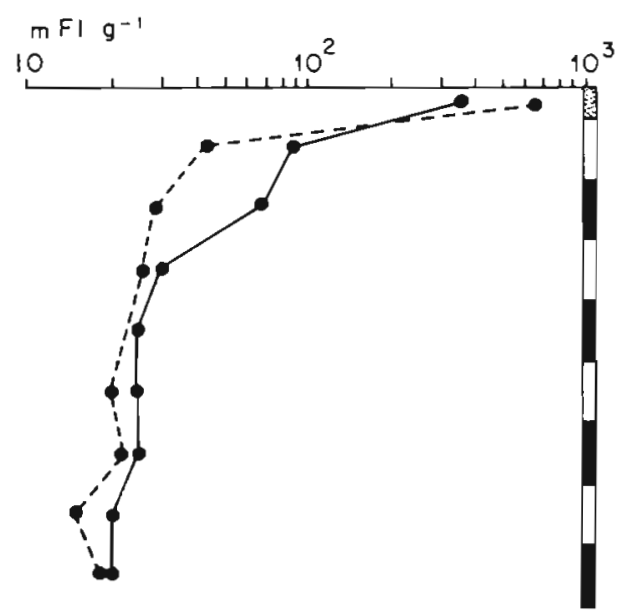

Fig. 3. Fluorescence of dissolved material in coral skeleton. Vertical scale indicates position of sample point in coral skeleton: stippled, coral surface layer; white and black part of bar, low and high density bands. Solid and broken lines are corals with and without fungus bands respectively

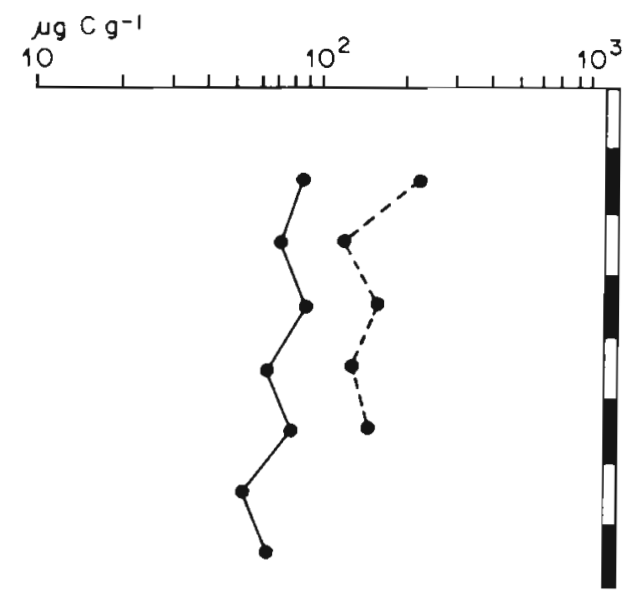

Fig. 4. Organic carbon concentrations in skeletons of corals with fungus bands. Vertical scale indicates position of sample points relative to coral surface and black banding pattern (represented by black and white parts of bar). Solid line: DOC; broken line: POC

black in color and represent a major part of the POC of the black bands. Microscopic examination of the skeleton around the dark filaments also showed a clear discoloration of the skeleton directly around the filaments. This material, probably an exudate of the organic filaments, is a component of the significantly higher DOC values of the black bands.

The filamentous mass consists of 2 constituents, a light-colored predominantly algal fraction and the dark dense mycelia of fungi. The common algal component was Ostreobium queketti Born. \& Flah. with reticulate chloroplasts and 2 to $5 \mu \mathrm{m}$ thick filaments. The major fungus, producing the dark hyphae and the occasionally occurring groups of perithecia (Fig. 5), is probably

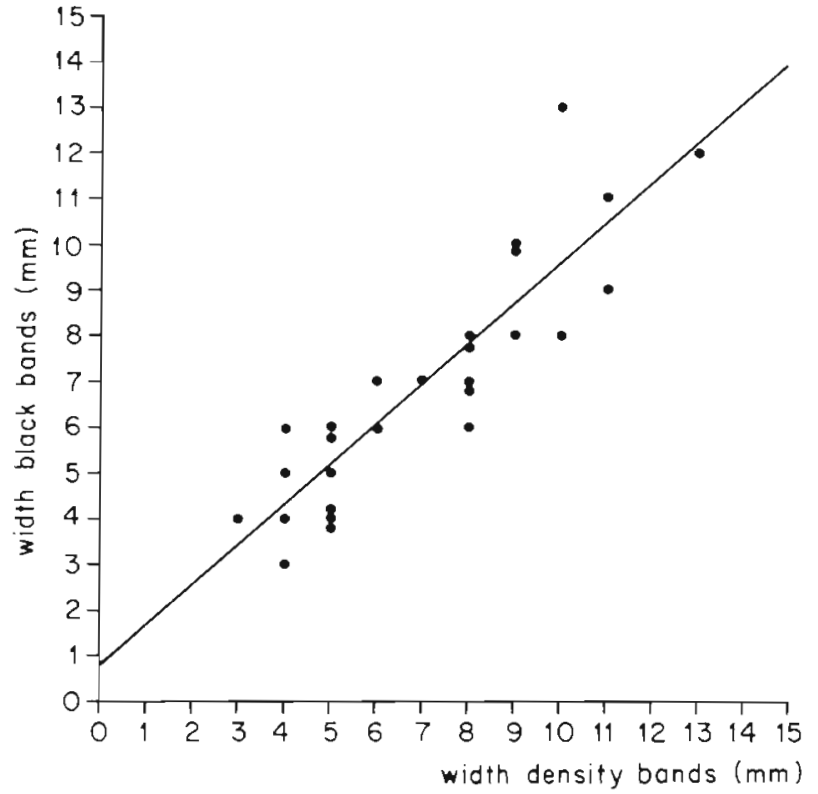

Fig. 5. Correlation between the spacing of black bands and coral skeletal density bands $(y=0.778+0.879 x, r=0.889)$

a member of the Halosphaeriaceae (Ascomycetes). From one sample a colorless fungus was isolated, Oospora halophila v. Beyma.

The black fungal discolorations occur only in our coral samples from Take Bone Rate and Salayer (Fig. 1), 2 out of the 8 areas sampled in eastern Indonesia. In both of these areas all massive Porites species were infected. The species can be ranked as follows from abundant to rare: $P$. lutea, $P$. australiensis, P. murrayensis, P. lobata, $P$. stephensoni and P. majori; but there were no significant differences in the proportion of colonies infected per species $\left(\chi^{2}, p>0.10\right)$. Within each of the 2 geographic areas the distribution of the fungus infections seems to be uneven. Off the southwest coast of Salayer, from Bahuluang to Malimbo, a distance of $20 \mathrm{~km}$, we collected massive Porites colonies at 7 sites. At 5 sites, 25 to $33 \%$ of the colonies $(n=6$ to 9 ) were infested but, at sites only 1 and $2 \mathrm{~km}$ away from the nearest infested collecting area we found no discolorations in the skeleton $(n=14)$. In the Take Bone Rate similar infestation rates were found at 7 sites over an area $14 \mathrm{~km}$ across from Tinandja and Taka Lamungan to Tarupa Besar ( $n=6$ to 11). Again only $6.4 \mathrm{~km}$ from the center of the area, at Taka Garlarang, no fungal infestations were found $(n=8)$.

The occurrence and spacing of the black bands and of the coral skeletal density bands is highly correlated (Fig. 5), because the fungus is concentrated in the low density areas. There was no relation between the presence/absence of black bands and the greater/smaller width of the density bands. Measurements of the width of pairs of high/low density bands, which are usually 
interpreted as annual growth, showed no significant differences (Kruskal-Wallis test, $\mathrm{p}>0.10$ ) between corals with and without fungus infestations (Table 1). There was no relation between the record of past damage to the living coral surfaces, visible as physical discontinuities in the sections through the colonies, and the presence of fungus infestations ( $\chi^{2}$ test, $\left.p>0.10\right)$.

\section{DISCUSSION}

Endolithic organisms in coral skeletons comprise a wide variety of taxa ranging from crustaceans to procaryotes (e.g. Golubic et al. 1975, Bromley 1978, Highsmith et al. 1983). It appears that research is focussed on groups such as sponges, molluscs and sipunculid/ polychaete worms rather than on algae, fungi and bacteria (Hutchings 1986). Of the latter groups - the microborers - the algae are relatively well studied. The species present in our Porites samples, Ostreobium queketti, is a dominant alga in coral skeletons, occurring deeper in the skeleton than most other algal species (Lukas 1973, van den Hoek et al. 1978). Concentrations of the algae occur in green bands, ranging from a superficial band very close to the colony surface to multiple additional bands deeper in the coral skeleton (Highsmith 1981). Bacteria have been isolated from insides of skeletons of Porites lobata (DiSalvo 1969).

Fungi are known to occur in marine substrata (Kohlmeyer 1969) but evidence of their penetration in coral skeletons is rather recent (Kendrick et al. 1982). At least a fairly large part of the species isolated from coral skeletons by these authors belong to common osmotolerant terrestrial genera and are in Kohlmeyer \& Kohlmeyer's (1979) terminology not obligatory but facultative marine fungi. The dark halosphaerian fungus of our Porites produces fruiting bodies opening directly into the marine environment, similar to the black perithecia of obligatory marine fungi (e.g. Kohlmeyer 1969).

Discolorations in coral skeletons have been almost exclusively related to the presence of algae. Greenish algal bands are a common phenomenon in corals, although reddish bands and blots are formed occasionally by the cyanophyte Plectonema terebrans Born. \& Flah. (Lukas 1973, 1974). Other discolorations described are light brown and related to the presence of chitinoclastic bacteria (DiSalvo 1969). DiSalvo (ibid.) also saw occasionally grey-black zones identified as sites of sulfate reduction. There was no trace of pyrites in our sample and the blackish discolorations described in this report are clearly caused by the dark fungal mycelia. Discolorations of calcareous material by fungal infestations have been described for marine calcareous substrate such as shells of molluscs, balanids and teredinid tubes (Kohlmeyer 1969, Kohlmeyer \& Kohlmeyer 1979). But such infestations are not very deep and never show such a conspicuous pattern.

The marine fungi described enter the calcareous substratum by an unknown mechanism. Etching has been suggested as a means of penetration (Hutchings 1986) and some hyphae appear to pass through the $\mathrm{CaCO}_{3}$ structures (Kendrick et al. 1982). Kohlmeyer (1969) suggests that fungi penetrate the calcareous material of shells through utilization of the organic (conchyolin) matrix. Coral skeletons are thought to contain a chitinous matrix (Wainwright 1963). This organic matrix was suggested as the substrate for possible bacterial invasions (DiSalvo 1969). A chitinous matrix could conveivably serve as a substrate for saprobic fungi, although very few higher chitinoclastic fungi have been recorded from the marine environment (Kohlmeyer \& Kohlmeyer 1979).

An alternative hypothesis is that the fungus penetrates through or along with the algae. Primary produc-

Table 1. Mean linear growth, measured as width of high/low density band pairs, in massive Porites. Our Indonesian samples include $P$. Iutea, $P$. australiensis, $P$. murrayensis, $P$. lobata, $P$. stephensoni and $P$. mayori

\begin{tabular}{|c|c|c|c|c|c|c|}
\hline Locality & Remarks & $\begin{array}{c}\text { Skeletal } \\
\text { conditions }\end{array}$ & $\begin{array}{l}\text { Growth } \\
\text { (mm) }\end{array}$ & $\mathrm{n}$ & $\begin{array}{l}\text { Depth } \\
(\mathrm{m})\end{array}$ & Source \\
\hline Salayer \& Take Bone Rate & Sites with fungus infestation & $\begin{array}{l}\text { Fungus } \\
\text { infection }\end{array}$ & $8.4 \pm 2.68$ & 11 & $6-11$ & This paper \\
\hline Salayer \& Take Bone Rate & Sites with fungus infestation & Normal & $8.7 \pm 2.26$ & 20 & $6-11$ & This paper \\
\hline Salayer \& Take Bone Rate & Sites without fungus infestation & Normal & $7.8 \pm 1.75$ & 8 & $7-10$ & This paper \\
\hline $\begin{array}{l}\text { East Indonesian } \\
\text { Archipelago }\end{array}$ & $\begin{array}{l}\text { Other sites visited on same } \\
\text { expedition }\end{array}$ & Normal & $8.3 \pm 2.74$ & 11 & $7-10$ & This paper \\
\hline Eniwetak & P. lutea, $P$. lobata & Normal & $10.8 \pm 2.01$ & 5 & $4-10$ & Buddemeier et al. 1974 \\
\hline Eniwetak & P. lutea & Normal & 7.6 & 30 & $0-30$ & Highsmith 1979 \\
\hline Great Barrier Reef & P. solida, P. lobata & Normal & $10.3 \pm 2.55$ & 4 & 2 & Potts et al. 1985 \\
\hline Hawaii (Oahu) & P. lobata & Normal & $8.1 \pm 2.37$ & 11 & $3-4$ & $\begin{array}{l}\text { Buddemeier \& Kinzie } \\
1975\end{array}$ \\
\hline
\end{tabular}


tion of the endolithic algae is low (Lewis 1976). Nevertheless, apart from facilitating penetration of the skeleton, the living aigae would also serve as an organic substrate for heterotrophs. The living algae are restricted to the outermost band in coral skeletons (Kanwisher \& Wainwright 1967) but deeper in the skeleton dead algae still offer a relatively rich organic substrate such as phaeophytin, remains of cell walls etc. Cyanophytes may also be active deeper inside coral skeletons (Crossland \& Barnes 1976) and serve as a source of organic material for fungi.

There was a green band visible directly under the layer of living coral tissue but multiple green bands deeper in the skeleton, were not conspicuous in our colonies. The space occupied by the superficial algal band is the low density band in the majority of the corals. Because all our samples were collected in September-October, it appears that this low density band is formed during the East monsoon, the dry season with higher light availability. Similar correlations of skeletal density and light regime have been observed (Buddemeier \& Kinzie 1975, Highsmith 1979, Charuchinda \& Chansang 1985). Light is probably a limiting factor for the endolithic algae (Halldal 1968, Shibata \& Haxo 1969). It is possible that the algae proliferate in this period of the year, when conditions for vigorous growth, i.e. light levels, are optimal in the coral skeleton (Highsmith 1981). The concentration of remains of Ostreobium queketti in the low density bands then explains the higher presence of fungus in these areas. The lack of a consistent density pattern in many corals is in accordance with the observations of Charuchinda \& Chansang (1985) that there is a considerable unexplained variation in banding patterns.

The geographic distribution of the fungus infections indicates that infection of skeletons is a rare event. The restricted distribution, only at reefs in southwest Sulawesi, suggests that long-distance dispersal through spores is not very successful. Also at an infected reef the rate of infection of individual colonies appears to be low. We have no samples of recently infected corals. Most skeletons display black discolorations through calcification periods of 10 to $20 \mathrm{yr}$. The blackish-grey discoloration is not completely absent between the dark bands and discoloration also occurs in discrete spots through a number of density bands indicating a continuous growth of the fungus over the years. It appears that a single fungus infection would suffice to infest a coral if the proper organic substrate is present. Even so only up to $33 \%$ of Porites populations showed the infections. That only a part of the Porites population is infested indicates that at the time of the presence of spores in the water, a minor proportion of the coral population must show some typical feature which facilitates infection, e.g. a fresh scar through the living coral surface into the zone of living endolithic algae.

The effects of a fungus infection on corals seem to be limited to 2 points. Firstly, fungus infections are a potential weakening of the corallum through breakdown of the organic matrix or through increased porosity (Highsmith 1981). Ascomycetes such as Pharcidia balani (Winter) Bauch can cause a softening of calcareous substrate (Kohlmeyer 1969). Such signs of a weathering effect were not discemible in our samples. A second obvious effect occurs because the fruiting bodies of the fungus appear as groups of cavities, the cavities opening in all cases on a dead area in the living coral surface (Fig. 5). This dead area must be created by the fungus and, like all dead spots on living coral surfaces, is a potential source of increased coral mortality through overgrowth or infestation of the coral by alien organisms (Bak \& Steward-van Es 1980).

This is the first observation of fungi as obvious participants in ecological processes on coral reefs. Surprisingly, their importance appears not to be limited to a minor trophic role. It appears that they interact actively with corals, and probably other organisms, in phenomena such as spatial competition. It seems unlikely that such interactions are limited to the coral genus Porites and to one corner of the ocean. We expect that closer studies of the interactions on living coral surfaces will show fungus/coral interaction to be common in certain reef areas. The ecological effects of fungi in spatial competition on coral reefs must then be assessed.

Acknowledgements. Our material was collected during the Snellius II expedition which was jointly organized by the Indonesian Institute of Science (LIPI) and the Netherlands Council of Oceanic Research (NRZ). We thank S van der Gaàst, J. Hegeman, J. Kalf, G. Nieuwland, R. Nolting (NIOZ) and Dr H. Dekkers (University Leiden) for their assistance in the laboratory analyses. Dr H. Moll identified the Porites species. We are grateful to Dr K. W. Gams and Dr A. de Cock (Bureau voor Schimmelcultures) and Prof. C. van den Hoek (University Groningen) for their kind help in identification of fungus and alga.

\section{LITERATURE CITED}

Bak, R. P. M. (1976). The growth of coral colonies and the importance of crustose coralline algae and burrowing sponges in relation with carbonate accumulation. Neth. J. Sea Res. 10: 285-337

Bak, R. P. M., Steward-van Es, Y (1980). Regeneration of superficial damage in the scleractinian corals Agaricia agaricites f. purpurea and Porites astreoides. Bull. mar. Sci. 30: 883-887

Barnard, L. A., Macintyre, I. G., Pierce, J. W. (1974). Possible environmental index in tropical reef corals. Nature, Lond. 252: $210-220$

Barnes, D. J. (1972). The structure and formation of growth 
ridges in scleractinian coral skeletons. Proc. R. Soc. Lond. (B) 182: 331-350

Boto, K., Isdale, P. (1985). Fluorescent bands in massive corals result from terrestrial fulvic acid inputs to nearshore zone. Nature, Lond. 315: 396-397

Bromley, R. G. (1978). Bioerosion of Bermuda reefs Palaeogeogr. Palaeoclimatol. Falaeoecol. 23: 169-197

Buddemeier, R. W. (1978). Coral growth: retrospective analysis. In: Stoddart, D. R., Johannes, R. E. (ed.) Coral reefs: research methods. Unesco, Paris

Buddemeier, R. W., Kinzie, R. A. (1975). The chronometric reliability of contemporary corals. In: Rosenberg, G. D., Runcorn, S. K. (ed.) Growth rhythms and the history of the earth's rotation. John Wiley, London, p. 135-147

Buddemeier, R. W., Maragos, J. E., Knutson, D. W. (1974). Radiographic studies of reef coral exoskeletons: rates and patterns of coral growth. J. exp. mar. Biol. Ecol. 14: $179-200$

Charuchinda, M., Chansang, H. (1985). Skeleton extension and banding formation of Porites lutea of the fringing reefs along the south and west coasts of Puket island (Thailand). Proc. 5th Int. Coral Reef Cong:., Tahiti 6: 83-87

Cortes, J., Risk, M. J. (1985). A reef under siltation stress: Cahuita, Costa Rica. Bull. mar. Sci. 36: 339-356

Crossland, C. J., Barnes, D. J. (1976). Acetylene reduction by coral skeletons. Limnol. Oceanogr. 21 153-155

Di Salvo, L. H. (1969). Isolation of bacteria from the corallum of Porites lobata (Vaughn) and its possible significance. Am. Zool. 9: 735-740

Dodge, R. E., Jickells, T. D., Knap, A. H., Boyd, S., Bak, R. P. M. (1984). Reef-building coral skeletons as chemical pollution (Phosphorus) indicators. Mar. Pollut. Bull. 15: 178187

Dodge, R. E., Vaisnys, J. R. (1980). Skeletal growth chronologies of recent and fossil corals. In: Rhodes, D. C., Lutz, R. A. (ed.) Skeletal growth chronoloties of aquatic organisms, Vol. I, Topics in geobiology. Plenum, New York, p. 493-517

Druffel, E. M. (1982). Banded corals: changes in oceanic carbon-14 during the little ice age. Science 218: 13-19

Emiliani, C., Hudson, J. H., Shinn, E. A., George, R. Y (1978). Oxygen and carbon isotopic growth record in a reef coral from the Florida Keys and a deep-sea coral from Blake Plateau. Science 202: 627

Flor, T. H., Moore, W. S. (1977). Radium/calcium and uranium/calcium determinations for western Atlantic reef corals. Proc. 3rd Int. Coral Reef Symp., Miami 2: 555-562

Golubic, S., Perkins, R. D., Lukas, K. J. (1975). Boring organisms and microborings in carbonate substrates. In: Frey, $R$. W. (ed.) The study of trace fossils. Springer-Verlag, New York, p. 229-259

Halldal, P. (1968). Photosynthetic capacities and photosynthetic action spectra of endozoic algae of the massive coral Favia. Biol. Bull. mar. biol. Lab., Woods Hole 134: 411-424

Highsmith, R. C. (1979). Coral growth rates and environmental control of density banding. J. exp. mar. Biol. Ecol. 37: $105-125$

Highsmith, R. C. (1981). Lime-boring algae in hermatypic coral skeletons. J. exp. mar. Biol. Ecol. 55: 267-281

Highsmith, R. C., Lueptow, R. L., Schonberg, S. C. (1983). Growth and bioerosion of three massive corals on the Belize barrier reef. Mar. Ecol. Prog. Ser. 13: 261-271

Hoek, C. van den, Breeman, A. M., Bak, R. P. M., Buurt, G. van (1978). The distribution of algae, corals and gorgo- nians in relation to depth, light attenuation, water movement and grazing pressure in the fringing reef of Curaçao, Netherlands Antilles. Aquat. Bot. 5: 1-46

Hudson, J. H., Shinn, E. A., Halley, R. B., Lidz, B. (1976). Sclerochronology - a tool for interpreting past environments. Geology 4: 361-364

Hutchings, P. A. (1986). Biological destruction of coral reefs. Coral Reefs $4: 239-252$

Isdale, P. (1984). Fluorescent bands in massive corals records centuries of coastal rainfall. Nature, Lond. 310: 578-579

Kanwisher, J. W., Wainwright, S. A. (1967). Oxygen balance in some reef corals. Biol. Bull. mar. biol. Lab., Woods Hole 133: $378-390$

Kendrick, B., Risk, M. J., Michaelides, J., Bergman, K. (1982). Amphibious microborers: bioeroding fungi isolated from live corals. Bull. mar. Sci. 32: 862-867

Knutson, D. W., Buddemeier, R. W., Smith, S. V. (1972). Coral chronometers - seasonal growth bands in corals. Science 177: $270-272$

Kohlmeyer, J. (1969). The role of marine fungi in the penetration of calcareous substances. Am. Zool. 9: 741-746

Kohlmeyer, J., Kohlmeyer, E. (1979). Marine mycology. The higher Fungi. Academic Press, New York

Laane, R. W. P. M. (1982). Chemical characteristics of the organic matter in the water fase of the Ems-Dollard estuary. Ph. D. thesis, Univ. of Groningen

Laane, R. W. P. M., Koole, L. (1982). The relation between fluorescence and dissolved organic carbon in the EmsDollart estuary and the western Wadden sea. Neth. J. Sea Res. 15: 217-227

Lewis, J. B. (1976). Processes of organic production on coral reefs. Biol. Rev. 52: 305-347

Lukas, K. J. (1973). Taxonomy and ecology of the endolithic microflora of reef corals with a review of the literature on endolithic microphytes. Ph. D. thesis, Univ. of Rhode Island

Lukas, K. J. (1974). Two species of the chlorophyte genus Ostreobium from Atlantic and Caribbean reef corals. J. Phycol. 10: 331-335

Ma, T. Y. H. (1934). On the seasonal change of growth in a reef Coral, Favia speciosa (Dana), and the water temperature of the Japanese seas during the latest geological times. Proc. imp. Acad. Japan. 10: 353-356

Macintyre, I. G., Smith, S. V. (1974). X-radiograph studies of skeletal development in coral colonies. Proc. 2nd Int. Symp. Coral Reefs, Brisbane 2: 277-287

Potts, D. C., Done, T. J., Isdale, P. J., Fisk, D. A. (1985). Dominance of a coral community by the genus Porites (Scleractinia). Mar. Ecol. Prog. Ser. 23: 79-84

Shibata, K., Haxo, F. T. (1969). Light transmission and spectral distribution through epi- and endozoic layers in the brain coral Favia. Biol. Bull. mar. biol. Lab., Woods Hole 136: $461-468$

St. John, B. E. (1974). Heavy metals in the skeletal carbonate of scleractinian corals. Proc. 2nd Int. Coral Reef Symp., Brisbane 2: 461-469

Wainwright, S. A. (1963). Skeletal organization in the coral, Pocillopora damicomis. Q. J. microsc. Sci. 104: 169-183

Weber, J. N., White, E. W., Weber, P. H. (1975). Correlation of density banding in reef coral skeletons with environmental parameters: the basis for interpretation of chronological records preserved in the coralla of corals. Paleobiol. 1: 137-149

Wells, J. W. (1963). Coral growth and geochronometry. Nature, Lond. 197: 948-950 